\title{
The effects of dexmedetomidine in increased intestinal permeability after traumatic brain injury: An experimental study
}

\author{
Onur Karaca, M.D., ${ }^{1}$ 일 Güvenç Doğan, M.D. ${ }^{2}$
}

\begin{abstract}
1'Department of Anesthesiology and Reanimation, Aksaray University Faculty of Medicine, Aksaray-Turkey ${ }^{2}$ Department of Anesthesiology and Reanimation, Hitit University Faculty of Medicine, Çorum-Turkey
\end{abstract}

\begin{abstract}
BACKGROUND: This study aims to investigate whether or not dexmedetomidine (DEX) application affects inflammation, increased intestinal mucosa damage and intestinal permeability in traumatic brain injury (TBI).

METHODS: The rats included in our study were randomized into three groups as the control group (Group I, $n=10)$, trauma group (Group 2, n=10) and the trauma+dexmedetomidine group (Group 3, $n=10$ ). While trauma was not induced in the control group, head trauma was induced in all rats in Groups 2 and 3 with the same method. The rats in Group 3 additionally received the DEX application. Intestinal THF-a, serum TNF-a, IL-6, IL-Ib and D-lactate levels were measured six hours post-trauma to assess systemic and local infection. Histopathological evaluation of the terminal ileum was performed at the 6 th hour to assess mucosal damage. Intestinal permeability was evaluated by measuring the level of dextran injected into the $5-\mathrm{cm}$ ileum segment adhered to the proximal and distal edges at the 30 th minute in the blood taken by cardiac puncture.
\end{abstract}

RESULTS: Intestinal TNF-a $(p=0.003)$, serum TNF-a $(p=0.009)$, IL-6 $(p=0.002)$, IL-Ib $(p=0.00 \mathrm{I})$, and $D$-lactate levels measured in Group $3(p=0.046)$ were significantly lower than those measured in Group 2. Dextran level measured in blood in Group 3 was observed significantly lower than that of Group $2(p<0.001)$. Histopathological evaluation of the intestines revealed no injuries in the ileum of the rats in Group I, injury in the ileum, villus atrophy and mucosal damage in the rats in Group 2, and a significant recovery was observed in Group 3 in comparison to Group 2.

CONCLUSION: It was seen in our study that DEX reduced TBI-induced increased inflammation, intestinal mucosa damage and intestinal permeability. These results suggest that DEX may ameliorate the damage done to the intestinal tissue by modulating post$\mathrm{TBI}$ inflammatory responses.

Keywords: Dexmedetomidine; intestinal mucosa damage; intestinal permeability; traumatic brain injury.

\section{INTRODUCTION}

Traumatic brain injury (TBI) is the impairment of brain functions due to a blow to the head, penetrating injury, or concussion. ${ }^{[1]}$ Except for conditions, such as neuromotor dysfunction, cognitive disorder and posttraumatic epilepsy, which develop in consequence to tissue damage, systemic physiological impairments, such as autonomic dysfunction, systemic inflammation and organ dysfunction can also occur. $^{[2]}$ Systemic inflammation plays an important role in the emergence of the gastrointestinal system (GIS) dysfunction seen as a result of traumatic brain injury. It has been reported that an increase in proinflammatory cytokines, including tumor necrosis factor-alpha (TNF-a), interleukin-6 (IL6) and interleukin I-beta (ILI-b), have a vital role in the process of intestinal damage and the increase in necrosis-dependent intestinal permeability may lead to bacterial translocation and even sepsis. Therefore, treatment modalities aimed at the

Cite this article as: Karaca O, Doğan G. The effects of dexmedetomidine in increased intestinal permeability after traumatic brain injury: An experimental study. Ulus Travma Acil Cerrahi Derg 2020;26:15-20.

Address for correspondence: Onur Karaca, M.D.

Aksaray Üniversitesi Eğitim ve Araştıma Hastanesi, Anesteziyoloji Anabilim Dalı, 68200 Aksaray, Turkey

Tel: +90382 - 2129109 E-mail: asalkaraca@gmail.com

Ulus Travma Acil Cerrahi Derg 2020;26(I):I5-20 DOI: 10.14744/tjtes.2019.49768 Submitted: 28.08.2019 Accepted: 29.10.2019 Online: 30.12.2019

Copyright 2019 Turkish Association of Trauma and Emergency Surgery 
prevention of GIS dysfunction are clinically crucial. ${ }^{[3-6]}$

As a highly selective alpha 2 adrenoceptor agonist, DEX is widely used in intensive care units (ICU) and during surgeries as a sedative and analgesic. ${ }^{[7,8]} \mathrm{DEX}$ is a potential agent with known anti-inflammatory and anti-apoptosis effects. [9,10] Moreover, it has been reported in previous studies that DEX significantly reduces serum TNF-a, interleukin 6 (IL-6) and interleukin I beta (IL-I $\beta$ ) levels in patients with intestinal damage. ${ }^{[11,12]}$ However, to our knowledge, the effects of DEX on TBI-dependent increased intestinal permeability have never been investigated despite its known anti-inflammatory effects. This study aimed to investigate whether the DEX application affects the increased intestinal mucosa damage and intestinal permeability in TBI.

\section{MATERIALS AND METHODS}

Animals

Ethical approval was obtained from the Experimental Animals Local Ethics Committee of Ankara Training and Research Hospital (date: 01.07.2019, no: 0054). Male Sprague-Dawley rats $(280-330 \mathrm{~g})$ were kept in separate cages at $23 \pm 2^{\circ} \mathrm{C}$ with a 12/12 dark/light cycle and fed with standard pellet feed and water. The rats were divided into three groups using a computer randomization procedure as the control group (Group I) $(n=10)$, trauma group (Group 2) and trauma+dexmedetomidine (Group 3) $(n=10)$. No trauma was induced and medication was administered in Group I. A cerebral contusion was induced in Groups 2 and 3 to achieve TBI with the method previously described by Bansal et al..$^{[5]}$ All groups were put under anesthesia with $75 \mathrm{mg} / \mathrm{kg}$ intraperitoneal ketamine (Ketalar ${ }^{\circledast}$, Pfizer Pharma GMBH, Germany) and $10 \mathrm{mg} / \mathrm{kg}$ xylazine hydrochloride (Alfazyne ${ }^{\circledR}, \% 2$, Alfasan International, $3440 \mathrm{AB}$, Woerden, the Netherlands). The head region of all rats was shaved with an electric razor by securing them in hand. A vertical incision was made on the cranium. Using a surgical drill, a hole $4 \mathrm{~mm}$ in diameter was drilled to reveal the durometer I $\mathrm{mm}$ lateral and posterior to the bregma. Afterwards, a metal ball weighing $250 \mathrm{gr}$ was dropped from a $2 \mathrm{~cm}$ height on to the durometer and the incision was closed. After the trauma, intravenous $5 \mathrm{uq} / \mathrm{kg} / \mathrm{h}$ DEX (Precedex, Dexmedetomidine $\mathrm{HCl} 200 \mathrm{mg} / 2 \mathrm{~mL}$ ) was administered for six hours in Group 3 , as applied in previous studies..$^{[9]}$

\section{Histopathological Evaluation}

When the abdominal cavity was opened to test intestinal permeability at the end of the sixth hour, samples were taken from the ileum. Intestinal samples were put in a $10 \%$ formaldehyde solution for the histological evaluation of the tissues and embedded in paraffin blocks by performing routine histological follow-ups. The sections were applied with periodic acid Schiff (PAS) staining for histopathological examinations. Each terminal ileum section was examined and classified by a blinded histopathologist.

\section{Intestinal Permeability (In-vivo Intestinal Permeability Assay)}

The animals were tested for intestinal permeability six hours after $\mathrm{TBI}$ as regards the method previously described ${ }^{[5]}$ After the application of anesthesia and DEX on all three groups, a midline laparotomy was performed. Following the fixation of the ileum and caecum, the $5-\mathrm{cm}$ terminal ileum segment was isolated. Previously prepared FITC-Dextran (25 mg $4.4 \mathrm{kDa}$ FITC-Dextran in $200 \mathrm{~mL}$ PBS) was injected into the lumen of the isolated ileum segment. The intestinal segment removed was put back into the abdominal cavity, and the abdominal wall was closed with 3.0 silk. Thirty minutes following injection, blood was taken with the cardiac puncture. Blood samples were put inside heparinized Eppendorf tubes and centrifuged at $10.000 \mathrm{~g}$ for ten minutes. After the separation of the plasma part, the test was completed using a SpectraMax M5 fluorescent spectrophotometer (Molecular Devices, Sunnyvale, CA) to determine FITC-Dextran concentration.

\section{Intestinal TNF-a Measurement}

Protein was extracted from the terminal ileum by homogenizing the tissue in $500 \mathrm{~mL}$ of ice-cold tissue protein extraction reagent (T-PER) containing $1 \%$ protease inhibitor and $1 \%$ phosphatase inhibitor (Pierce Biotechnology). Homogenates were centrifuged at $10,000 \mathrm{~g}$ for $5 \mathrm{~min}$. The supernatant was obtained and stored at -708C. Intestinal TNF-a was measured in Groups 2 and 3 using a commercially available ELISA assay (R\&D system, Minneapolis, MN). Values were reported as $\mathrm{pg} / \mathrm{mL}$.

\section{Blood TNF-a, IL-6, IL-1B Measurement}

Commercially available ELISA kits were used to measure the levels of TNF-a, IL-6 and IL-Ib (R\&D System, Minneapolis, Minn) utilizing a SpectraMax M2e Microplate Spectrophotometer (Bio-RAD, Berkeley, CA) as instructed by the manufacturer. Six hours after the DEX application, the test was performed taking blood from the intraabdominal aorta when the abdominal cavity as opened for dextran testing.

\section{D-Lactate Measurement}

Plasma D-lactate levels were measured using a D-lactate Colorimetric Test Kit (BioVision, Milpitas, CA) as instructed by the manufacturer. Test samples were prepared in a 96-gouged plate with test tampons and mixed with the reaction mixture for 30 minutes at room temperature. Optic density was measured at $450 \mathrm{~nm}$. A series of D-lactate standard solutions was diluted and the standard curve was given, and hence the concentration of the samples was measured.

\section{Statistical Methods}

Statistical analyses were conducted using SPSS (Version 22.0, SPSS Inc., Chicago, IL, USA). Descriptive statistics were presented as mean \pm standard deviation values. Distributions of the data were evaluated using Shapiro-Wilk tests. Homogeneity of variance was evaluated by the Levene test. The significance of 
Table I. Comparison of intestinal TNF- $\alpha$, TNF- $\alpha$, IL-6, IL-IB, Dextran and D-lactate according to rat groups

\begin{tabular}{|c|c|c|c|c|c|}
\hline & Groups & $\mathbf{n}$ & Mean $\pm S D$ & P-values & Post-hoc P-values \\
\hline Intestinal & $\mathrm{TBI}$ & 8 & $44.00 \pm 8.78$ & $0.003^{\mathrm{a}}$ & - \\
\hline TNF- $\alpha(p g / m L)$ & $\mathrm{TBI}+\mathrm{DEX}$ & 8 & $29.50 \pm 6.90$ & & \\
\hline \multirow[t]{3}{*}{ TNF- $\alpha$ (pg/mL) } & Sham & 8 & $1.70 \pm 0.45$ & $<0.00 \mathrm{I}^{\mathrm{b}}$ & $\mathrm{I}-2:<0.00 \mathrm{I}$ \\
\hline & TBI & 8 & $3.63 \pm 0.61$ & & I-3: 0.001 \\
\hline & $\mathrm{TBI}+\mathrm{DEX}$ & 8 & $2.72 \pm 0.25$ & & 2-3: 0.009 \\
\hline \multirow[t]{3}{*}{ IL-6 (pg/mL) } & Sham & 8 & $1.62 \pm 1.06$ & $<0.00 \mathrm{I}^{\mathrm{b}}$ & I-2: <0.00I \\
\hline & $\mathrm{TBI}$ & 8 & $52.62 \pm 13.60$ & & I-3: $0.00 \mathrm{I}$ \\
\hline & $\mathrm{TBI}+\mathrm{DEX}$ & 8 & $25.62 \pm 11.50$ & & 2-3: 0.002 \\
\hline \multirow[t]{3}{*}{ IL-IB (pg/mL) } & Sham & 8 & $2.23 \pm 0.92$ & $<0.00 \mathrm{I}^{\mathrm{b}}$ & $\mathrm{I}-2:<0.00 \mathrm{I}$ \\
\hline & $\mathrm{TBI}$ & 8 & $11.08 \pm 2.67$ & & I-3: <0.00I \\
\hline & $\mathrm{TBI}+\mathrm{DEX}$ & 8 & $4.96 \pm 0.89$ & & 2-3: 0.001 \\
\hline \multirow[t]{3}{*}{ Dextran (ug/mL) } & Sham & 8 & $|8.8| \pm 2.64$ & $<0.00 \mathrm{I}^{\mathrm{b}}$ & $\mathrm{I}-2:<0.00 \mathrm{I}$ \\
\hline & TBI & 8 & $68.7 I \pm 16.33$ & & I-3: 0.002 \\
\hline & $\mathrm{TBI}+\mathrm{DEX}$ & 8 & $25.02 \pm 7.09$ & & $2-3:<0.001$ \\
\hline \multirow[t]{3}{*}{ D-Lactate $(\mathrm{mmol} / \mathrm{L})$} & Sham & 8 & $0.65 \pm 0.15$ & $0.00 I^{c}$ & $\mathrm{I}-2:<0.00 \mathrm{I}$ \\
\hline & TBI & 8 & $1.10 \pm 0.25$ & & I-3: 0.109 \\
\hline & $\mathrm{TBI}+\mathrm{DEX}$ & 8 & $0.85 \pm 0.13$ & & 2-3: 0.046 \\
\hline
\end{tabular}

a'Student's t-test. 'ANOVA with Games-Howell post hoc test. 'ANOVA with Tukey HSD post hoc test.

TBI: Traumatic brain injury; DEX: Dexmedetomidine; TNF- $\alpha$ : tumor necrosis factor-alpha; IL-6: Interleukin-6; IL-IB: Interleukin I-beta; SD: Standard deviation.

the difference between more than two groups was evaluated using the one-way ANOVA test since data met the assumptions of normality. Post-hoc tests with Tukey HSD or GamesHowell were used to determine which groups differed with pairwise comparison according to the homogeneity of the variances. A value of $p<0.05$ was considered statistically significant.

\section{RESULTS}

Statistical comparisons of intestinal TNF- $\alpha$, TNF- $\alpha$, IL-6, IL-
IB, Dextran and D-lactate by rat groups are given in Table I. There was a statistically significant difference between the rat groups concerning intestinal TNF- $\alpha$ (pg/mL), TNF- $\alpha(\mathrm{pg} / \mathrm{mL})$, IL-6 (pg/mL), IL-IB (pg/mL), Dextran (ug/mL) and D-Lactate $(\mathrm{mmol} / \mathrm{L})$ parameters (Table $\mathrm{I})$. There was a difference between all groups according to the results of the Post hoc test (Table I). Boxplots for comparison of intestinal Dextran, D-lactate, TNF- $\alpha$, TNF- $\alpha$, IL-6, and IL-IB according to rat groups are shown in Figure $\mathrm{I}$ and 2.
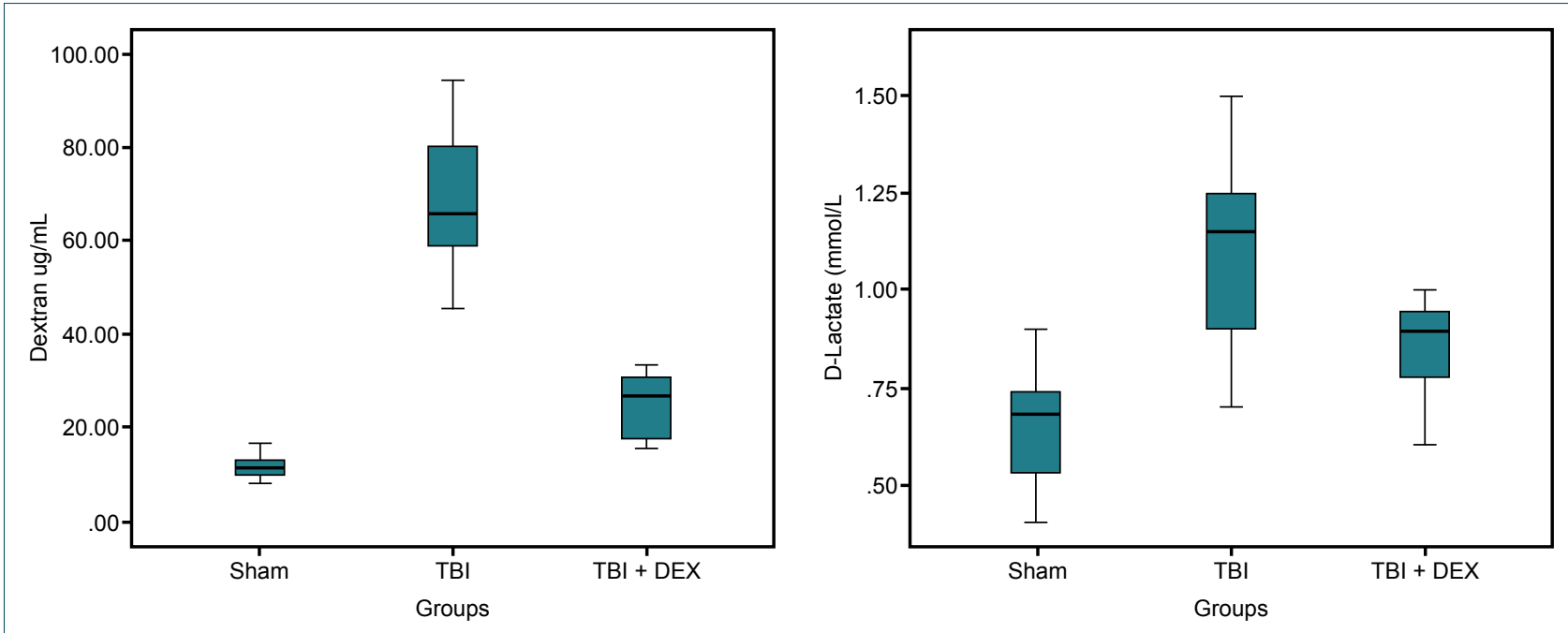

Figure 1. Boxplot for comparison of Dextran and D-lactate by rat groups. 


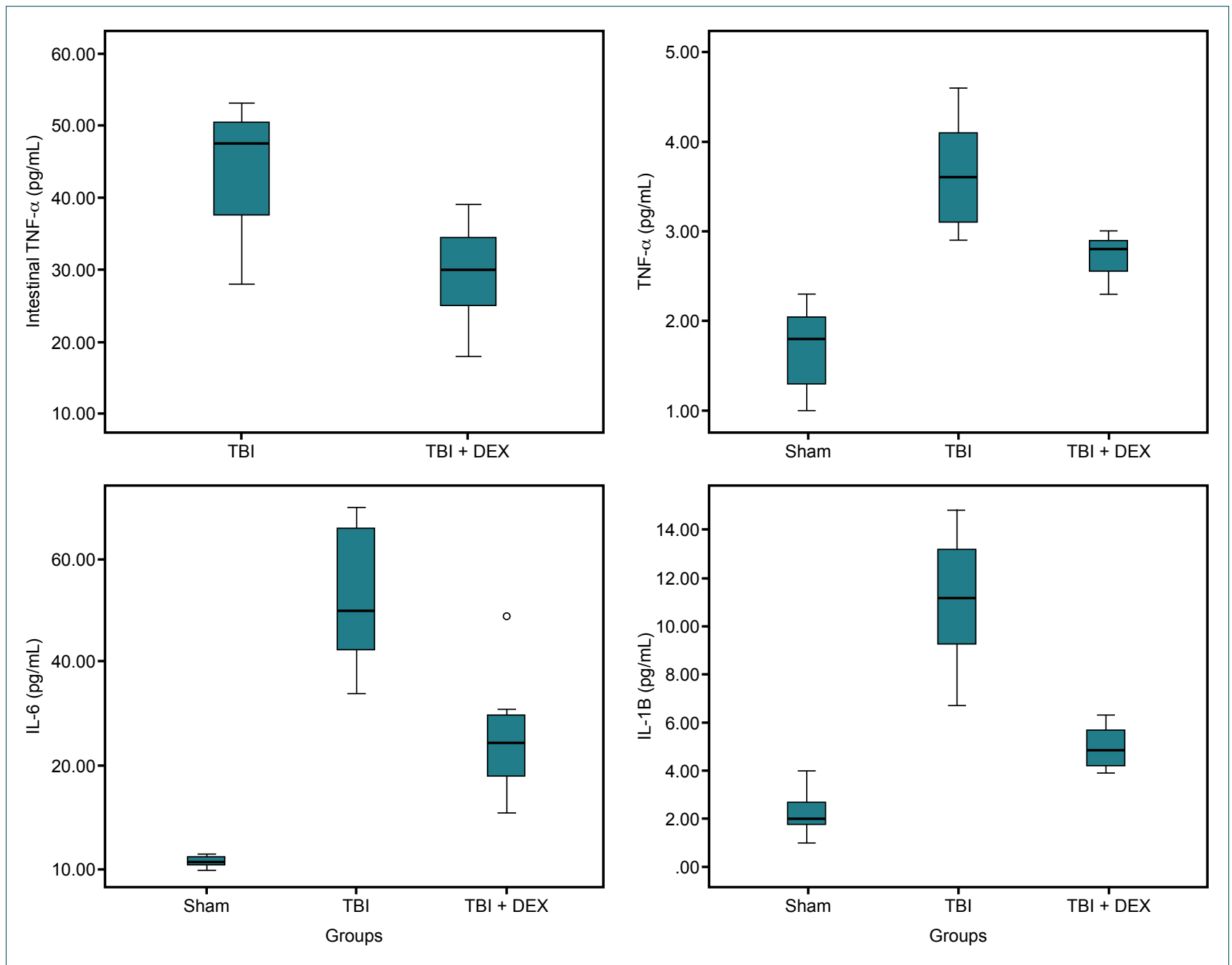

Figure 2. Boxplot for comparison of intestinal TNF- $\alpha$, TNF- $\alpha$, IL-6, and IL-1B by rat groups.

\section{Histopathological Findings}

Images in intestinal tissues are presented in Figures 3, 4 and 5.

\section{DISCUSSION}

To our knowledge, our study is the first investigating the

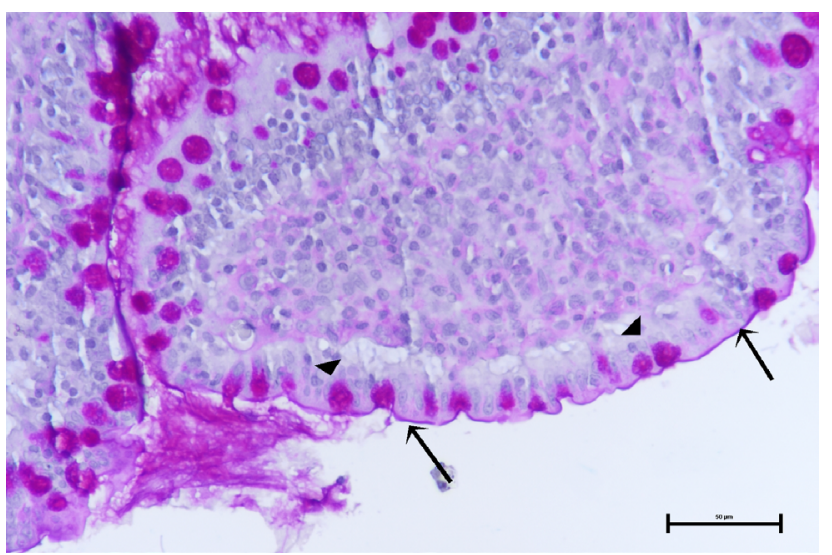

Figure 3. Histological section of group 1 ileum. Undamaged single columnar epithelial cells and (arrows) apical region shows a brush border. (arrowheads) goblet cells (400x). effects of the DEX on post-TBI intestinal damage and permeability. We put forth with this study that DEX, which is widely used in intensive care and anesthetic applications, has curative effects on post-TBI systemic inflammation, increased intestinal permeability and intestinal mucosa.

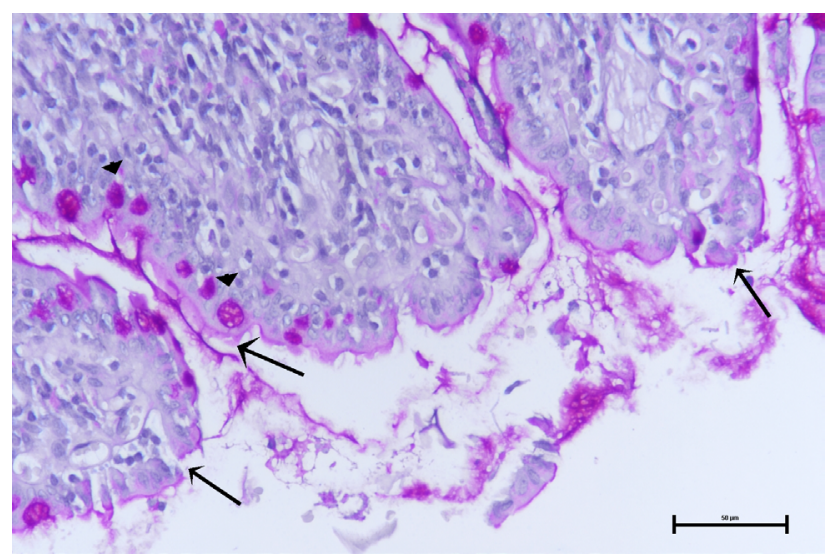

Figure 4. Histological section of group 2 ileum. General damaged single columnar epithelial cells and (arrows) brush border (arrowheads) goblet cells $(400 \mathrm{x})$. 


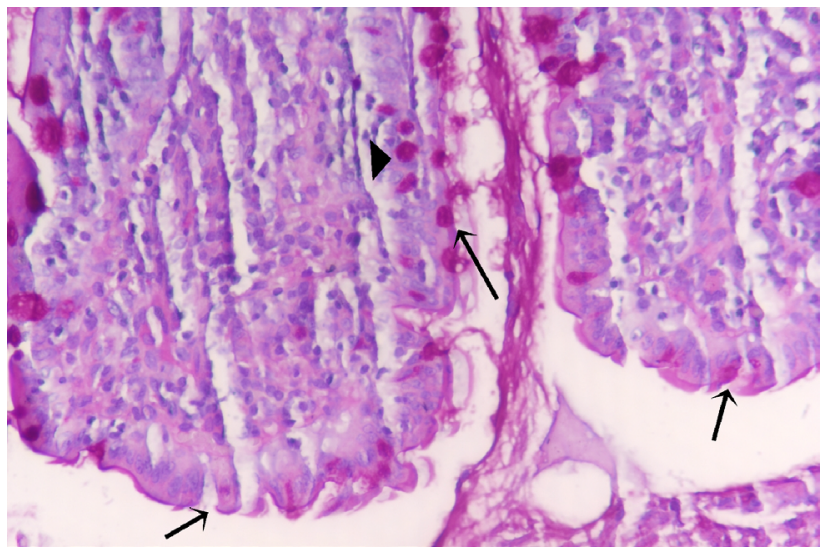

Figure 5. Histological section of group 3 ileum. Partial damaged single columnar epithelial cells and (arrows) brush border (arrowheads) goblet cells $(400 x)$.

Previous studies have concluded that D-lactate shows the severity of the intestinal damage and also changes consistently with the epithelial function of the intestinal barrier are among microbiota metabolites. ${ }^{[13]}$ In this study, we found serum D-lactate levels in Group 3 significantly lower than those in Group 2 , which provided us with important evidence that the intestinal mucosa barrier was protected as regards the trauma group.

Studies in the literature show an immediate increase in the level of proinflammatory cytokines (TNF-a, IL-I, IL-6, IL-I2) after TBI. ${ }^{[4,14,15]}$ Again, Tamion et al. ${ }^{[16]}$ have reported that the increase in inflammatory cytokines, such as TNF-a, IL-I $\beta$ and IL-6, plays an important role in the intestinal damage process. By activating systemic inflammatory response together with the endotoxins in circulation, the intestinal immune system may cause multiple organ failure. Many studies have demonstrated that systemic inflammatory cytokines are correlated to intestinal damage. ${ }^{[17,18]}$ In this study, a significant increase was observed in the systemic inflammatory cytokines (TNF-a, IL-6, IL-IB) of the trauma group, which in turn expressed that systemic inflammatory response may lead to intestinal damage.

Previous studies on TBI have determined that intestinal permeability that develops due to systemic and local inflammation is a problem leading to serious life-threatening complications like sepsis in critical patients. ${ }^{[6]}$ Severe damage may occur in the intestinal structure after TBI. Thus, its barrier function is destroyed. The deterioration of the intestinal integrity starts at as early as the third hour of brain injury and specifically results in mucosal atrophy on the seventh day. Morphological changes, such as mucosal atrophy on the intestinal mucosa, destruction of binding proteins between epithelial cells, villus loss, focal ulcerations, neighboring villus fusion, villus interstitium and edema in lamina propria, can be seen. This deep mucosal damage causing the anatomical deterioration of the intestinal barrier leads to an increase in intestinal permeability in the end. ${ }^{[19]}$ In this study, we histologically ensured amelioration and significant improvement in the villus structure in Group 3 in comparison to Group 2.
It is to our belief that this improvement was realized by the anti-inflammatory effects of DEX.

Chen et al. ${ }^{[9]}$ have emphasized that DEX improves intestinal damage by reducing systemic inflammation. Furthermore, previous studies have shown that DEX inhibits the expression of inflammatory mediators containing $\mathrm{NO}$, prostaglandin E2, TNF-a and IL-6. ${ }^{[20]}$ Previously conducted studies on rats have found that the use of the DEX leads to a decrease in the expression of TNF-a in ischemic hippocampal tissue and in the TNF-a and IL-6 concentrations in rats exposed to endotoxins. $^{[21,22]}$ Again, Kayhan et al. ${ }^{[23]}$ have shown the immunomodulatory effects and suppressive effects of DEX on proinflammatory cytokines in a colitis model they have generated. As a result of finding low levels of cytokine in our rat model that received DEX, we suggested that DEX suppressed systemic inflammation, which in turn provided us with evidence indicating that DEX may ameliorate intestinal mucosa damage by preventing systemic inflammation of the intestinal damage.

Limitations to our study include that previous studies have mentioned that DEX has curative effects in ischemia-reperfusion damage and surgery-related stress response on the intestinal tissue by increasing intestinal blood flow. ${ }^{[24]}$ We could not evaluate this parameter since we lacked the facilities to show the microcirculation of the intestinal tissue after the DEX application. Again, we failed to examine the status of the intestinal mucosal interties since we did not have the means to examine the intestinal tissue immunohistochemically. These results have provided data on the curative effects s of DEX on the intestinal tissue by modulating inflammatory responses after TBI.

\section{Conclusion}

In conclusion, we observed that DEX ameliorated TBI-induced systemic inflammation and increased intestinal permeability. We believe that further studies are needed for DEX, which is a mediator to the protection of intestinal tissue post-TBI.

\section{Acknowledgment}

We thank Ercan Ayaz from the Histology and Embryology Department for assistance with our histological evaluation. In addition, we want to thank Yasin Kenesarı from the Department of Medical Biochemistry for assistance with our biochemistry evaluation. Finally, we want to thank Emre Demir from the Department of Biostatistics for statistical analysis assistance.

Ethics Committee Approval: Approved by the local ethics committee (date: 01.07.2019, no: 0054).

Peer-review: Internally peer-reviewed.

Authorship Contributions: Concept: O.K., G.D.; Design: O.K., G.D.; Supervision: O.K., G.D.; Fundings: O.K., G.D.; Materials: O.K., G.D.; Data: O.K., G.D.; Analysis: O.K., G.D.; Literature search: O.K., G.D.; Writing: O.K., G.D.; Critical revision: O.K., G.D.

\section{Conflict of Interest: None declared.}

Financial Disclosure: The autors declared that this study has received no financial support. 


\section{REFERENCES}

1. Dilmen ÖK, Akçıl EF, Tunalı Y. Intensive Care Treatment in Traumatic Brain Injury. Turk J Anaesthesiol Reanim 2015;43:1-6. [CrossRef]

2. Baguley IJ, Heriseanu RE, Cameron ID, Nott MT, Slewa-Younan S. A critical review of the pathophysiology of dysautonomia following traumatic brain injury. Neurocrit Care 2008;8:293-300. [CrossRef]

3. Cook AM, Peppard A, Magnuson B. Nutrition considerations in traumatic brain injury. Nutr Clin Pract 2008;23:608-20. [CrossRef]

4. Kemp CD, Johnson JC, Riordan WP, Cotton BA. How we die: the impact of nonneurologic organ dysfunction after severe traumatic brain injury. Am Surg 2008;74:866-72.

5. Bansal V, Costantini T, Kroll L, Peterson C, Loomis W, Eliceiri B, et al. Traumatic brain injury and intestinal dysfunction: uncovering the neuroenteric axis. J Neurotrauma 2009;26:1353-9. [CrossRef]

6. Feighery L, Smyth A, Keely S, Baird AW, O'Connor WT, Callanan JJ, et al. Increased intestinal permeability in rats subjected to traumatic frontal lobe percussion brain injury. J Trauma 2008;64:131-7. [CrossRef]

7. Brandão PG, Lobo FR, Ramin SL, Sakr Y, Machado MN, Lobo SM. Dexmedetomidine as an Anesthetic Adjuvant in Cardiac Surgery: a Cohort Study. Braz J Cardiovasc Surg 2016;31:213-8. [CrossRef]

8. Venn RM, Bradshaw CJ, Spencer R, Brealey D, Caudwell E, Naughton $C$, et al. Preliminary UK experience of dexmedetomidine, a novel agent for postoperative sedation in the intensive care unit. Anaesthesia 1999;54:1136-42. [CrossRef]

9. Chen Y, Miao L, Yao Y, Wu W, Wu X, Gong C, et al. Dexmedetomidine Ameliorate CLP-Induced Rat Intestinal Injury via Inhibition of Inflammation. Mediators Inflamm 2015;2015:918361. [CrossRef]

10. Taniguchi T, Kidani Y, Kanakura H, Takemoto Y, Yamamoto K. Effects of dexmedetomidine on mortality rate and inflammatory responses to endotoxin-induced shock in rats. Crit Care Med 2004;32:1322-6. [CrossRef]

11. Li B, Li Y, Tian S, Wang H, Wu H, Zhang A, et al. Anti-inflammatory Effects of Perioperative Dexmedetomidine Administered as an Adjunct to General Anesthesia: A Meta-analysis. Sci Rep 2015;5:12342. [CrossRef]

12. Memiş D, Hekimoğlu S, Vatan I, Yandim T, Yüksel M, Süt N. Effects of midazolam and dexmedetomidine on inflammatory responses and gastric intramucosal $\mathrm{pH}$ to sepsis, in critically ill patients. $\mathrm{Br} \mathrm{J}$ Anaesth
2007;98:550-2. [CrossRef]

13. Lorenz I, Vogt S. Investigations on the association of D- lactate blood concentrations with the outcome of therapy of acidosis, and with posture and demeanour in young calves with diarrhea. J Vet Med A 2006;53:490-4.

14. Hang CH, Shi JX, Li JS, Li WQ, Wu W. Expressions of intestinal NFkappaB, TNF-alpha, and IL-6 following traumatic brain injury in rats. J Surg Res 2005;123:188-93. [CrossRef]

15. Lenz A, Franklin GA, Cheadle WG. Systemic inflammation after trauma. Injury 2007;38:1336-45. [CrossRef]

16. Tamion F, Richard V, Lacoume Y, Thuillez C. Intestinal preconditioning prevents systemic inflammatory response in hemorrhagic shock. Role of HO-1. Am J Physiol Gastrointest Liver Physiol 2002;283:G408-14.

17. Doğan G, İpek H, Baş Y, Doğan G, Kayır S. Experimental study on prophylactic effects of vardenafil in ischemia-reperfusion model with intestinal volvulus injury in rats. J Pediatr Surg 2019;54:2172-7. [CrossRef]

18. Özkan N, Ersoy ÖF, Özsoy Z, Çakır E. Melatonin exhibits supportive effects on oxidants and anastomotic healing during intestinal ischemia/reperfusion injury. Ulus Travma Acil Cerrahi Derg 2018;24:1-8. [CrossRef]

19. Hang CH, Shi JX, Li JS, Wu W, Yin HX. Alterations of intestinal mucosa structure and barrier function following traumatic brain injury in rats. World J Gastroenterol 2003;9:2776-81. [CrossRef]

20. Lin CY, Tsai PS, Hung YC, Huang CJ. L-type calcium channels are involved in mediating the anti-inflammatory effects of magnesium sulphate. Br J Anaesth 2010;104:44-51. [CrossRef]

21. Eser O, Fidan H, Sahin O, Cosar M, Yaman M, Mollaoglu H, et al. The influence of dexmedetomidine on ischemic rat hippocampus. Brain Res 2008;1218:250-6. [CrossRef]

22. Taniguchi T, Kurita A, Kobayashi K, Yamamoto K, Inaba H. Dose- and time-related effects of dexmedetomidine on mortality and inflammatory responses to endotoxin-induced shock in rats. J Anesth 2008;22:221-8.

23. Erdogan Kayhan G, Gul M, Kayhan B, Gedik E, Ozgul U, Kurtoglu EL, et al. Dexmedetomidine ameliorates TNBS-induced colitis by inducing immunomodulator effect. J Surg Res 2013;183:733-41. [CrossRef]

24. Sun Y, Gao Q, Wu N, LI SD, Yao JX, Fan WJ. Protective effects of dexmedetomidine on intestinal ischemia reperfusion injury. Exp Ther Med 2015;10:647-52. [CrossRef]

\section{DENEYSEL ÇALIŞMA - ÖZET}

\section{Travmatik beyin hasarında artmış bağırsak geçirgenliğine deksmedetomidinin etkisi: Deneysel çalı̧̧ma}

\section{Dr. Onur Karaca, ${ }^{1}$ Dr. Güvenç Doğan²}

\section{${ }^{1}$ Aksaray Üniversitesi Tıp Fakültesi, Anestezi ve Reanimasyon Anabilim Dalı, Aksaray}

${ }^{2}$ Hitit Üniversitesi Tıp Fakültesi, Anestezi ve Reanimasyon Anabilim Dalı, Çorum

AMAÇ: Deksmedetomidin (DEX) uygulamasının travmatik beyin hasarında $(\mathrm{TBH})$ enflamasyonu, artan bağırsak mukoza hasarını ve bağırsak geçirgenliğini etkileme durumu araştırıldı.

GEREÇ VE YÖNTEM: Çalışmamızda değerlendirdiğimiz hayvanlar kontrol grubu (Grup I, n= I0), travma grubu (Grup 2, n= I0) ve travma + deksmetetomdin grubu (Grup 3, n= I0) olmak üzere üç gruba randomize edildi. Kontrol grubuna travma uygulanmazken, Grup 2 ve 3'deki sıçanların hepsine aynı yöntemle kafa travması uygulandı. Grup 3'deki sıçanlara ek olarak intraperitoneal DEX uygulaması yapıldı. Sistemik ve lokal enflamasyonu değerlendirmek için travmadan 6 saat sonra bağırsak TNF-a, serum TNF-a, IL-6, IL-Ib, D-laktat düzeyleri ölçüldü. Mukoza hasarını değerlendirmek için 6. saatte terminal ileumun histopatolojik incelemesi yapıldı. İntestinal geçirgenliği değerlendirmek için ise proksimal ve distal uçlarından bağlanan $5 \mathrm{~cm}$ 'lik ileum segmentine enjekte edilen dekstranın 30. dakikada kardiyak ponksiyonla alınan kandaki düzeyi ölçüldü.

BULGULAR: Grup 3'te ölçülen bağırsak TNF-a ( $p=0.003)$, serum TNF-a $(p=0.009)$, IL-6 $(p=0.002), I L-I b(p=0.00 I)$, D-laktat düzeyleri $(p=0.046)$, Grup 2'ye göre anlamlı ölçüde düşük saptandı. Grup 3'te kanda ölçülen dekstran düzeyi Grup 2'ye göre anlamlı düzeyde düşük gözlendi ( $p<0.00 \mathrm{I}$ ). Bağırsakların histopatolojik incelemesinde ise; Grup I'deki sıçanların ileumunda hasar yok, Grup 2'deki sıçanların ileumunda; villus atrofisi ve mukozal hasar, Grup 3'dekilerin ise Grup 2'ye göre anlamlı derecede iyileşme olduğu gözlendi.

TARTıŞMA: Çalışmamızda DEX'in TBı kaynaklı artan enflamasyonu, bağırsak mukoza hasarını ve bağırsak geçirgenliğini azalttığı görüldü. Bu sonuç lar, DEX'in, TBH sonrası enflamatuvar yanıtları modüle ederek bağırsak dokusuna verilen hasarı iyileştirebileceğini göstermiştir. Anahtar sözcükler: Bağırsak mukoza hasarı; deksmedetomidin; intestinal geçirgenlik; travmatik beyin hasarı.

Ulus Travma Acil Cerrahi Derg 2020;26(I):15-20 doi: 10.14744/tjtes.2019.49768 